\title{
Primary clear cell sarcoma of the femur: a unique case with RT-PCR and direct sequencing confirmation of EWSR1/ATF1 fusion gene
}

Yuta Kubota', Kazuhiro Tanaka ${ }^{1 *}$ (D, Masanori Hisaoka², Tsutomu Daa ${ }^{3}$, Tatsuya Iwasaki ${ }^{1}$, Masanori Kawano ${ }^{1}$, Ichiro Itonaga ${ }^{1}$ and Hiroshi Tsumura ${ }^{1}$

\begin{abstract}
Background: It is very rare for clear cell sarcomas (CCS) to arise in the bone. During diagnosis, it is important to distinguish primary CCS of bone from bone metastasis of melanoma because this difference fundamentally changes the therapeutic options. Recently, characteristic fusion genes of CCS have been detected using reverse transcription polymerase chain reaction (RT-PCR) or direct sequencing which allowed to distinguish CCS from melanoma. However, there was no study applying these analyses with positive results. In this case, we describe the use of fusion gene analysis to diagnose a primary CCS of the bone.

Case presentation: A 36-year-old male presented with a four-months history of left knee pain. Magnetic resonance imaging showed a lesion in the left femoral medial epicondyle. Histological examination of the biopsy specimen revealed proliferating oval or rounded cells. These cells had clear cytoplasm arranged in fascicles or compact nests with frequent deposits of brown pigment. Furthermore, immunohistochemistry analysis revealed that tumor cells were positive for S-100 protein, HMB-45, Melan-A, and SOX10. It stained negative for CD34 and BRAF v600e. Conclusively, detection of the EWSR1/ATF1 fusion gene using RT-PCR and direct sequencing confirmed that the lesion was a primary CCS of the bone. Wide-margin resection and reconstruction with a tumor endoprosthesis were performed.

Conclusions: Herein, we diagnosed a rare case of primary CCS of the bone by detecting EWSR1/ATF1 fusion gene using RT-PCR and direct sequencing. Since fluorescence-in situ hybridization (FISH) and RT-PCR could show false positive by mainly due to technical problems, it is better to perform direct sequencing to confidently diagnose the tumor as a primary CCS especially at very rare site such as bone.
\end{abstract}

Keywords: Clear cell sarcoma, Primary bone tumor, Melanoma, Fusion gene, Direct sequencing, Reverse transcription polymerase chain reaction

\footnotetext{
* Correspondence: ktanaka@oita-u.ac.jp

'Department of Orthopaedic Surgery, Faculty of Medicine, Oita University,

1-1 Idaigaoka Hasama, 879-5593 Yufu City, Oita, Japan

Full list of author information is available at the end of the article
}

(c) The Author(s). 2021 Open Access This article is licensed under a Creative Commons Attribution 4.0 International License, which permits use, sharing, adaptation, distribution and reproduction in any medium or format, as long as you give appropriate credit to the original author(s) and the source, provide a link to the Creative Commons licence, and indicate if changes were made. The images or other third party material in this article are included in the article's Creative Commons licence, unless indicated otherwise in a credit line to the material. If material is not included in the article's Creative Commons licence and your intended use is not permitted by statutory regulation or exceeds the permitted use, you will need to obtain permission directly from the copyright holder. To view a copy of this licence, visit http://creativecommons.org/licenses/by/4.0/. The Creative Commons Public Domain Dedication waiver (http://creativecommons.org/publicdomain/zero/1.0/) applies to the data made available in this article, unless otherwise stated in a credit line to the data. 


\section{Background}

Clear cell sarcoma (CCS) was first described by Enzinger in 1965 [1]. It is a malignant soft tissue tumor arising from tendons and aponeuroses. CCS has limited treatment options because effective radiotherapy and chemotherapy regimens have not been established for this type of tumor. The five-year survival rate of CCS is $47 \%$ and the 10-year survival rate is only $36 \%$, [2] demonstrating the aggressive nature of this tumor. CCS is rare, and accounts for less than $1 \%$ of soft-tissue sarcomas [1]. It is very rare for CCS to be localized in the bone. To our knowledge, there are currently only 13 reports in English describing primary CCS of the bone (Table 1) [315]. The first primary CCS of the bone was reported in the right ulna by Yokoyama et al. [3]. They diagnosed the neoplasm as CCS on the basis of both histopathological and immunohistochemical features including the presence of S-100 protein, HMB-45, and vimentin. Their findings were consistent with those of both melanoma and CCS, but they seemed to be more closely related to CCS. However, their examination findings were as a result of techniques that did not involve cytogenetic analysis, which was not commonly used and the appropriate method for which had not been established until then; therefore, they could not definitely rule out melanoma as the diagnosis [3, 16]. Panagopoulos et al. [17]. examined EWS/ATF1 fusion genes in CCS of soft tissue using reverse transcription polymerase chain reaction (RTPCR) amplification and sequence analysis in 2002. Coindre et al. [18]. detected EWS/ATF1 fusion transcripts in 38 paraffin-embedded CCS tissues out of 41 interpretable samples (93\%) in 2006. This study showed that RTPCR on paraffin-embedded tissues was useful for distinguishing CCS from melanoma. Furthermore, RT-PCR demonstrated that EWSR1/CREB1 fusion gene was another fusion gene of CCS [19]. The EWS/ATF1 fusion gene has also been detected using fluorescence in-situ hybridization (FISH) in bone CCS samples [10, 11, 15]. In contrast, there are no reports confirming whether the EWS/ATF1 or EWSR1/CREB1 fusion genes can be detected using direct sequencing. In this article, we report a case of CCS in the femur with the EWS/ATF1 fusion gene detected using direct sequencing and RT-PCR.

\section{Case presentation}

A 36-year-old male presented with a four-months history of pain in the left knee. His medical history was negative for injury, among others, as the underlying cause. Physical examination revealed a tenderness at the left femoral medial epicondyle but no swelling, redness or heat around the joint. Furthermore, there was no instability or joint contracture. Radiological examination showed an osteolytic lesion in the femoral medial epicondyle with a partially destructed cortex (Fig. 1). There was no sclerotic rim or periosteal reaction. Computed tomography $(\mathrm{CT})$ revealed a $38 \times 19 \times 17 \mathrm{~mm}$ osteolytic lesion that partially destroyed and thinned the cortex (Fig. 2). There was no calcification in the mass. Magnetic resonance imaging (MRI) showed that the lesion had the most hypointense area, including both hyperintense and isointense areas heterogeneously on T1-weighted images and had hyperintense areas with septal walls on T2weighted images. Hyperintense signal areas were observed at the femoral articular surface without extraosseous soft tissue signal change (Fig. 3). Considering all images, giant cell tumor (GCT), osteosarcoma or chondrosarcoma was suspected.

Open biopsy was performed for a definitive diagnosis. Histological examination revealed that oval or rounded cells were proliferating. These cells had clear cytoplasm arranged in fascicles or compact nests with frequent deposits of brown pigment (Fig. 4). For a more accurate evaluation of the tumor type, immunohistochemistry was performed using a panel of markers. This analysis revealed that tumor cells were positive for S-100 protein, HMB-45, Melan-A, and SOX10. It stained negative for CD34 and BRAF v600e. Considering these features [20], the main differential diagnoses were clear cell sarcoma and melanoma. RT-PCR and direct sequencing are the molecular techniques that help differentiate between the different EWS/ATF1 fusion types and breakpoints [1921]; therefore, we used both the methods. We examined the tumor for EWSR1/ATF1 transcripts using RT-PCR (Fig. 5) and direct sequencing on the paraffin-embedded tissue (Fig. 6). The tumor was found to be positive for the EWSR1/ATF1 fusion gene. Thus, we diagnosed the patient with primary clear cell sarcoma of the bone.

As CCS of the bone is so rare, extensive investigations were conducted to search for other metastases or primary tumors. The patient's skin was checked by a dermatologist, but no melanoma was found. Whole-body CT and positron emission tomography (PET)/CT were performed and showed no other metastatic dissemination.

Based on our investigations, we concluded that this was a primary CCS localized to the bone. Because CCS does not usually respond to radiotherapy or chemotherapy [22],

adjuvant therapy was not applied to this patient. A wide-margin resection and reconstruction with an endoprosthesis were performed. We presumed that the tumor invaded the intra-articular area as the CT image showed a partially destroyed femoral medial epicondyle cortex. Accordingly, we performed an extra-articular knee resection including the suprapatellar bursa and joint capsule. The resected specimen had a pathologically confirmed negative margin and the tumor spread extraskeletally at the femoral medial epicondyle but not into the soft tissue around the capsule. Nine months after surgery, no local recurrence or metastases were detected. 
Table 1 Reported cases of primary CCS of bone $(n=13)$

\begin{tabular}{|c|c|c|c|c|c|c|c|}
\hline Author & $\begin{array}{l}\text { Age/ } \\
\text { Sex }\end{array}$ & Location & $\begin{array}{l}\text { General screening for } \\
\text { primary lesion including } \\
\text { melanoma }\end{array}$ & Immunohistochemistry & Genetic analysis & Treatment & Follow up \\
\hline $\begin{array}{l}\text { Yokoyama } \\
\text { et al. [3] }\end{array}$ & $33 / F$ & Right ulna & Various radiograph & $\begin{array}{l}\text { Positive: S-100, HMB-45, } \\
\text { vimentin } \\
\text { Negative: desmin, keratin }\end{array}$ & Not performed & $\begin{array}{l}\text { Neoadjuvant: Ifosfamide, cisplatin } \\
\text { and doxorubicin } \\
\text { Wide margin resection } \\
\text { Adjuvant: cisplatin and } \\
\text { doxorubicin }\end{array}$ & $\begin{array}{l}\text { CDF, } 65 \\
\text { months after } \\
\text { surgery }\end{array}$ \\
\hline $\begin{array}{l}\text { Brekke } \\
\text { et al. [4] }\end{array}$ & $62 / F$ & $\begin{array}{l}\text { Right first } \\
\text { metatarsal }\end{array}$ & ${ }^{99} \mathrm{~m}$ Tc MDP bone scan & $\begin{array}{l}\text { Positive: S-100 protein, } \\
\text { vimentin } \\
\text { Negative: HMB- } 45 \text {, cytokeratin } \\
\text { (AE1/AE2) }\end{array}$ & Not described & Syme's amputation & $\begin{array}{l}\text { CDF, } 15 \\
\text { months after } \\
\text { surgery }\end{array}$ \\
\hline $\begin{array}{l}\text { Gelczer } \\
\text { et al. [5] }\end{array}$ & $\begin{array}{l}18 / \\
M\end{array}$ & $\begin{array}{l}\text { Left ninth } \\
\text { rib }\end{array}$ & $\begin{array}{l}\mathrm{CT},{ }^{99 \mathrm{~m}} \mathrm{~T} \mathrm{C} \mathrm{MDP} \text { bone scan, } \\
\text { bone marrow aspirate }\end{array}$ & Positive: S-100 protein, HMB-45 & Not described & $\begin{array}{l}\text { Neoadjuvant: Performed but } \\
\text { details were not described } \\
\text { Wide resection } \\
\text { Adjuvant: doxorubicin, } \\
\text { cyclophosphamide, vincristine }\end{array}$ & $\begin{array}{l}\text { CDF, } 55 \\
\text { months after } \\
\text { treatment }\end{array}$ \\
\hline $\begin{array}{l}\text { Inaoka } \\
\text { et al. [6] }\end{array}$ & $\begin{array}{l}55 / \\
M\end{array}$ & $\begin{array}{l}\text { Right } \\
\text { radius }\end{array}$ & 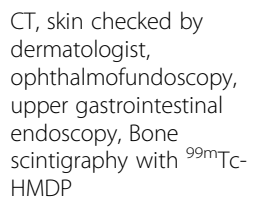 & $\begin{array}{l}\text { Positive:S-100 protein, HMB- } 45 \text {, } \\
\text { vimentin }\end{array}$ & $\begin{array}{l}\text { Negative (method not } \\
\text { described) }\end{array}$ & $\begin{array}{l}\text { Neoadjuvant: cisplatin and } \\
\text { doxorubicin } \\
\text { Total tumor resection }\end{array}$ & $\begin{array}{l}\text { CDF, } 18 \\
\text { months after } \\
\text { primary } \\
\text { surgery }\end{array}$ \\
\hline $\begin{array}{l}\text { Choi et al. } \\
\text { [7] }\end{array}$ & $48 / F$ & $\begin{array}{l}\text { Right first } \\
\text { metatarsal }\end{array}$ & $\begin{array}{l}\mathrm{CT} \text {, whole body } \\
\text { radioisotope scan }\end{array}$ & $\begin{array}{l}\text { Positive: S-100, HMB- } 45 \\
\text { Negative: cytokeratin, epithelial } \\
\text { membrane antigen }\end{array}$ & Not performed & $\begin{array}{l}\text { Below-knee amputation of the } \\
\text { right leg }\end{array}$ & $\begin{array}{l}\text { DOD, } 20 \\
\text { months after } \\
\text { surgery }\end{array}$ \\
\hline $\begin{array}{l}\text { Hersekli } \\
\text { et al. [8] }\end{array}$ & $28 / F$ & $\begin{array}{l}\text { Left ninth } \\
\text { rib }\end{array}$ & $\begin{array}{l}\mathrm{CT} \text {, skin checked by } \\
\text { dermatologist, Bone } \\
\text { scintigraphy with }{ }^{99 \mathrm{~m}} \mathrm{Tc} \text { - } \\
\mathrm{HMDP} \text { and }{ }^{67} \mathrm{Ga}\end{array}$ & Positive:S-100 protein, HMB-45 & FISH: negative & $\begin{array}{l}\text { Total tumor resection } \\
\text { adjunctive radiotherapy of } \\
500 \mathrm{cGy}\end{array}$ & $\begin{array}{l}\text { CDF, } 33 \\
\text { months }\end{array}$ \\
\hline $\begin{array}{l}\text { Kazakos } \\
\text { et al. [9] }\end{array}$ & $\begin{array}{l}61 / \\
M\end{array}$ & $\begin{array}{l}\text { Left } \\
\text { scapula }\end{array}$ & Bone scanning, $\mathrm{CT}$ & $\begin{array}{l}\text { Positive: S-100, HMB- } 45, \text { NSE, } \\
\text { EMA, cytokeratin, myosin }\end{array}$ & Not described & $\begin{array}{l}\text { Wide resection } \\
\text { Adjuvant: ifosfamide, vincristine } \\
\text { and epirubicin }\end{array}$ & $\begin{array}{l}\text { DOD, } 15 \\
\text { months after } \\
\text { adjuvant } \\
\text { chemotherapy }\end{array}$ \\
\hline $\begin{array}{l}\text { Rocco } \\
\text { et al. [10] }\end{array}$ & $\begin{array}{l}53 / \\
M\end{array}$ & sternum & $C T, P E T$, bone scans & $\begin{array}{l}\text { Positive: S-100, TFE3 } \\
\text { Negative: HMB- } 45, \text { MART1, } \\
\text { cytokeratins, epithelial mem- } \\
\text { brane antigen, renal cell car- } \\
\text { cinoma, CD10, chromogranins, } \\
\text { synaptophysin, inhibin, } \\
\text { calretinin }\end{array}$ & FISH: positive & Wide resection & Not described \\
\hline $\begin{array}{l}\text { Zhang } \\
\text { et al. [11] }\end{array}$ & $\begin{array}{l}25 / \\
M\end{array}$ & sacrum & $\begin{array}{l}\text { CT, MRI (thorax and } \\
\text { abdomen), Bone } \\
\text { scintigraphy with }{ }^{99 \mathrm{~m} T \mathrm{C}^{-}} \\
\text {HMDP, skin, oral, anal and } \\
\text { fundus oculi checked }\end{array}$ & $\begin{array}{l}\text { Positive: S-100, HMB-45, Melan- } \\
\text { A } \\
\text { Negative: EMA, CD117, CD34, } \\
\text { MSA, GFAP, PGM-1, RCC, MIB- } \\
\text { 1, AE1/AE3, CEA, Des, and } \\
\text { HBME-1 }\end{array}$ & FISH: positive & Curettage and debridement & $\begin{array}{l}\text { AWD, } 9 \\
\text { months after } \\
\text { surgery }\end{array}$ \\
\hline $\begin{array}{l}\text { Liu et al. } \\
{[12]}\end{array}$ & $20 / F$ & $\begin{array}{l}\text { Proximal } \\
\text { right } \\
\text { humerus }\end{array}$ & 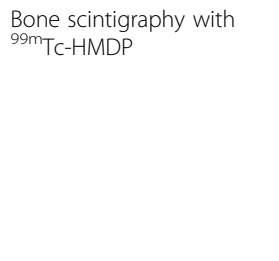 & Positive: S-100, HMB-45 & FISH: negative & $\begin{array}{l}\text { Neoadjuvant: cisplatin and } \\
\text { doxorubicin } \\
\text { Total tumor excision- } \\
\text { alcoholization-replantation, in- } \\
\text { ternal fixation and bone cement } \\
\text { implantation } \\
\text { Adjuvant: cisplatin, doxorubicin } \\
\text { and } \\
\text { methotrexate }\end{array}$ & $\begin{array}{l}\text { CDF, } 1 \text { year } \\
\text { after } \\
\text { treatment }\end{array}$ \\
\hline $\begin{array}{l}\text { Nakayama } \\
\text { et al. [13] }\end{array}$ & $\begin{array}{l}81 / \\
M\end{array}$ & $\begin{array}{l}\text { Left pubic } \\
\text { bone }\end{array}$ & $\begin{array}{l}\mathrm{CT}, \mathrm{PET} / \mathrm{CT} \text {, Bone } \\
\text { scintigraphy with }{ }^{99 \mathrm{~m}} \mathrm{Tc}- \\
\mathrm{HMDP},{ }^{67} \mathrm{Ga} \text {-citrare } \\
\text { scintigraphy, skin checked } \\
\text { by dermatologist }\end{array}$ & $\begin{array}{l}\text { Positive: S-100, HMB-45, Melan- } \\
\text { A } \\
\text { Negative: cytokeratin, epithelial } \\
\text { membrane antigen }\end{array}$ & $\begin{array}{l}\text { FISH: negative, } \\
\text { direct sequencing } \\
\text { BRAF mutation: } \\
\text { negative }\end{array}$ & $\begin{array}{l}\text { Dimethyl triazeno imidazole } \\
\text { carboxamide, 1-[4-amino-2- } \\
\text { methyl-5-pyrimidinyl]-methyl-3- } \\
\text { [2-chloroethyl]-3-nitrosourea } \\
\text { hydrochloride and vincristin, } \\
\text { radiotherapy }\end{array}$ & DOD \\
\hline $\begin{array}{l}\text { Licata } \\
\text { et al. [14] }\end{array}$ & $\begin{array}{l}42 / \\
M\end{array}$ & $\begin{array}{l}\text { Left third } \\
\text { metatarsus }\end{array}$ & Bone scan & $\begin{array}{l}\text { Positive: S-100, HMB-45, Melan- } \\
\text { A } \\
\text { Negative: cytokeratin, epithelial } \\
\text { membrane antigen }\end{array}$ & Not described & transtibial amputation & Not described \\
\hline $\begin{array}{l}\text { Xu et al. } \\
{[15]}\end{array}$ & $\begin{array}{l}61 / \\
M\end{array}$ & $\begin{array}{l}\text { Right } \\
\text { calcaneus }\end{array}$ & $\begin{array}{l}\text { Bone scintigraphy with } \\
\text { 99mTc-HMDP }\end{array}$ & $\begin{array}{l}\text { Positive: S-100, vimentin, } \\
\text { melanA } \\
\text { Negative: HMB45, NSE, SMA, }\end{array}$ & $\begin{array}{l}\text { Positive (method not } \\
\text { described) }\end{array}$ & Below-knee amputation & $\begin{array}{l}\text { CDF, at the } 6 \\
\text { months } \\
\text { follow-up }\end{array}$ \\
\hline
\end{tabular}


Table 1 Reported cases of primary CCS of bone $(n=13)$ (Continued)

\begin{tabular}{|c|c|c|c|c|c|c|c|}
\hline Author & $\begin{array}{l}\text { Age/ } \\
\text { Sex }\end{array}$ & Location & $\begin{array}{l}\text { General screening for } \\
\text { primary lesion including } \\
\text { melanoma }\end{array}$ & Immunohistochemistry & Genetic analysis & Treatment & Follow up \\
\hline & & & & $\begin{array}{l}\text { desmin, CD117, CD99, } \\
\text { cytokeratin }\end{array}$ & & & \\
\hline $\begin{array}{l}\text { Kubota } \\
\text { et al. (The } \\
\text { present } \\
\text { study) }\end{array}$ & $\begin{array}{l}36 / \\
M\end{array}$ & $\begin{array}{l}\text { Left } \\
\text { Femur }\end{array}$ & $\begin{array}{l}\text { skin checked by } \\
\text { dermatologist, Whole-body } \\
\mathrm{CT}, \mathrm{PET} / \mathrm{CT}, \mathrm{MRI} \text { (femur, } \\
\text { upper limb, spine) }\end{array}$ & $\begin{array}{l}\text { Positive: S-100, HMB-45, mel- } \\
\text { anA, vimentin, Sox10, INI-1, } \\
\text { EMA, CD99, TLE-1, Ki67 } \\
\text { Negative: AE1/AE3, CD34, } \\
\text { CD56, LCA, WT-1, BRAF v600e, } \\
\text { H3.3G34, Fli-1, ERG, NKX2.2 }\end{array}$ & $\begin{array}{l}\text { RT-PCR, direct } \\
\text { sequence of } \\
\text { transcripts and found } \\
\text { EWSR1-exon } 8 \\
\text { forward and ATF1- } \\
\text { exon } 4 \text { reverse (type } \\
\text { 1) }\end{array}$ & $\begin{array}{l}\text { Wide margin resection and distal } \\
\text { femoral replacement using } \\
\text { cemented rotating hinge } \\
\text { prosthesis }\end{array}$ & $\begin{array}{l}\text { CDF, } 9 \\
\text { months after } \\
\text { surgery }\end{array}$ \\
\hline
\end{tabular}

CT Computed tomography, PET Positron emission tomography, MRI Magnetic resonance imaging, $F$ Female, $M$ Male, ${ }^{99 m} T c M D P$ Tc-99m-methylene diphosphonate, CDF Continuous disease free, DOD Died of disease, AWD Alive with disease, RT-PCR Reverse transcription polymerase chain reaction, FISH Fluorescent in-situ hybridization

\section{Discussion}

The first report resembling primary malignant CCS of bone was presented by Yokoyama et al. [3] in 1996. In this first case, they did not collect material for genetic analysis and therefore, could not

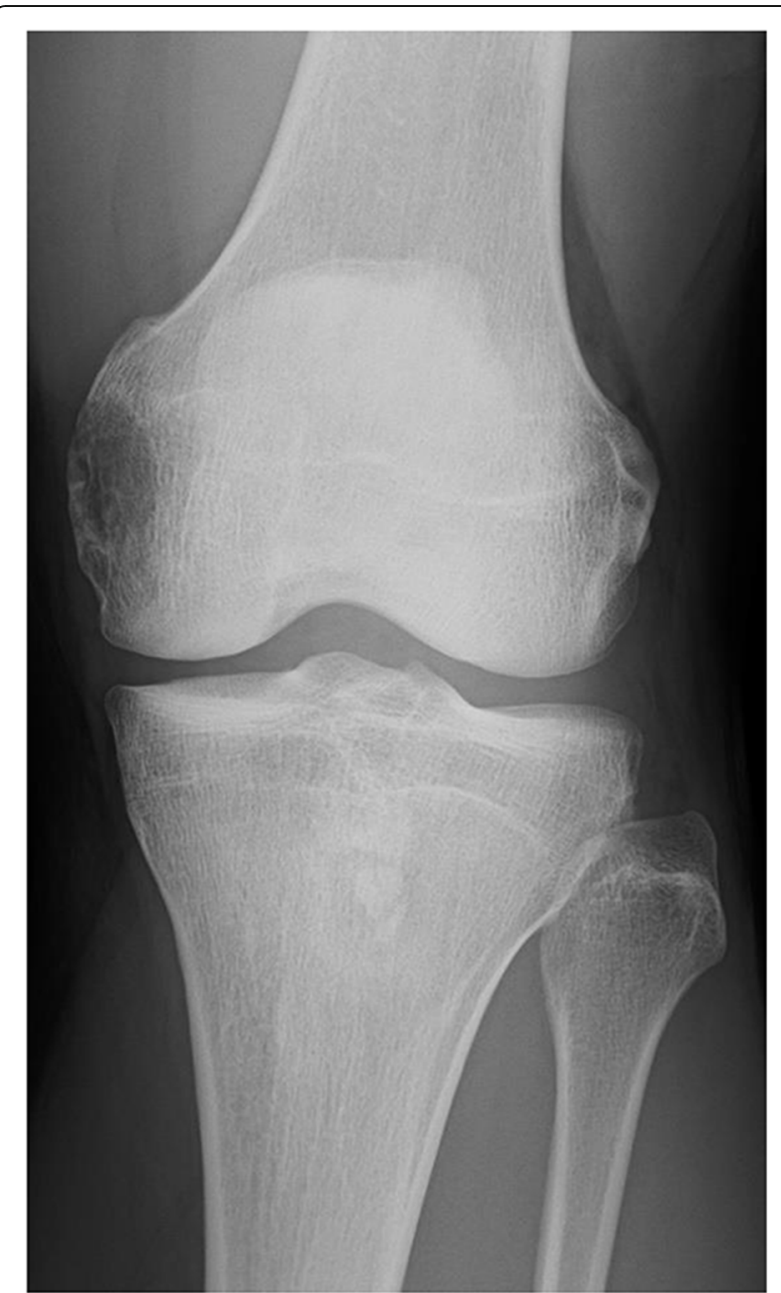

Fig. 1 Radiograph shows osteolytic lesion in the left distal femur definitely diagnose CCS of bone without verification of the $t(12 ; 22)$ translocation; instead they suggested a diagnosis of either melanoma or CCS of the bone $[3,16]$. It has been reported that $\mathrm{t}(12 ; 22)(\mathrm{q} 13-14$; q12) translocation was detected in $62.5 \%-70 \%$ of CCS cases, and that the tumors negative for it required histopathological diagnosis [17, 23].

It is very important to distinguish primary CCS of the bone from bone metastasis of melanoma as they share many common histopathological features; however CCS of the bone is very rare. Compared to melanoma, CCS typically lacks significant nuclear pleomorphism [24]. CCS is also usually strongly positive for HMB- 45, S-100, Melan-A, MITF, and negative for smooth muscle actin, desmin and keratin $[819,24,25]$. Melanoma, on the other hand, is typically positive for c-kit, CD68, S-100, HMB-45, Melan$\mathrm{A}$, throsinase, and vimentin, and negative for smooth muscle actin, desmin, chromogranin, and epithelial membrane antigen [24, 25]. However, each case of CCS varies, and the overlapping staining profiles between CCS and melanoma suggest that immunohistochemical examination alone cannot discriminate between these tumors. We used S-100 protein, HMB45, Melan-A, SOX10, CD34, and BRAF v600e for histopathological examination. As mentioned above, S-100 protein, HMB-45, and Melan-A are usually positive in CCS and melanoma [24]. Positive staining for SOX10 is suggestive of CCS because EWS/ATF1 activates melanocyte-specific MITF-SOX10 expression [26]. BRAF was reported to be rare in CCS [27]. but positive in clear cell melanoma and melanoma [28]. Similarly, CCS is negative for CD34 [19]. CD34 is useful to distinguish CCS from Epithelioid neoplasms with SMARCB1 and SMARCA4 deficiency or Mesenchymal tumors with NTRK fusions which are positive for CD34 [29].

Since 1996, diagnoses of primary CCS of the bone have been supported by further evidence including: (1) 


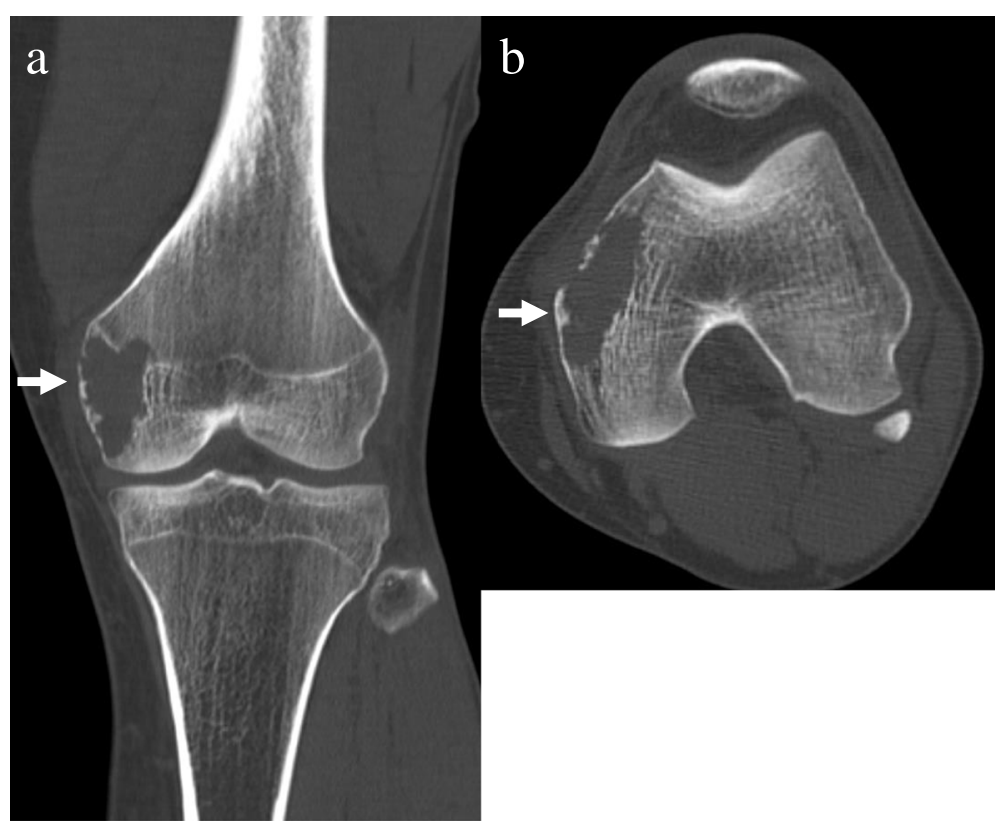

Fig. 2 Computed tomography scans show a lytic lesion with partial cortical destruction in the distal femur. Lytic lesions (arrows) with partial cortical destruction are shown in (a) 3D coronal view and (b) Axial view

whole body screening tests such as PET-CT that showed no melanoma, $[10,13](2)$ no previous history of melanoma, $[7,9]$ and (3) patients survived much longer than those with bone metastasis of melanoma [3,6].

Meanwhile, EWSR1/ATF1 and EWSR1/CREB1 transcript fusions have been identified in CCS. [30, 31] Hisaoka et al. [19] reported that 33 CCSs analyzed using RT-PCR were positive for transcripts of either EWSR1/ATF1 type 1,2,3,4, or EWSR1/CREB1. The case we have presented here was positive for the type 1 fusion transcript of EWSR1/ATF1, consisting of the forward EWSR1/exon 8 and reverse ATF1-exon 4.

To our knowledge, 13 cases of primary CCS of the bone have been reported in the literature, as shown in Table 1. The first genetic analysis was conducted by Rocco et al. in 2009 [10]. Although they confirmed rearrangement of the EWS gene localized on chromosome 22q12 using FISH, fusion transcripts were not detected. When seven of the 13 known cases of primary CCS of the bone were assessed for chromosomal translocation by cytogenetic analysis including FISH, only three cases were positive $[10,11,15]$. Of the four negative cases, the one reported by Inaoka et al. [6] was deemed a primary CCS of bone rather than melanoma as their patient survived for more than 18 months, which is significantly longer than the mean survival of 4.7 months for patients with melanoma [32]. Two other cases by Hersekli et al. [8] and Liu et al. [12] concluded on primary CCS of the bone based on morphological and immunoenzymatic features only. The last case described by Nakayama et al. [13] reported that whole body screening (CT, PET/ $\mathrm{CT}$ ), bone scintigraphy, and a skin check by a dermatologist were all negative for primary melanoma; therefore, their case was diagnosed as primary CCS of the bone. All cases describing the method of cytogenetic analysis used FISH. Nakayama et al. [13] also performed BRAF (exons 11 and 15) mutation analysis using direct sequencing.

However, there were possibilities that RT-PCR and FISH produce false positive results due to technical problems although it might be rare, [33-38] and that not all the best probes and primers for known fusion genes with optimal conditions were used in all 13 cases. Thus, we are still unable to definitively conclude that all thirteen reported cases were primary CCS of the bone.

Furthermore, dual-color, break-apart FISH using breakapart rearrangement specific for EWSR1 gene on 22q13 is usually used for distinguishes clear cell sarcoma of soft tissue from melanoma, [39] but using the probe does not suggest fusion types or breakpoints of EWS gene rearrangement [19-21]. Moreover, CCS cases with EWS/ ATF1 fusion gene but not translocation $\mathrm{t}(12 ; 22)$ (q13;q1213) have been reported [17]. FISH test might not be appropriate for these cases. On the other hand, RT-PCR amplification carryover contamination leads to false-positive PCR reactions [40], and positive and negative controls for all fusion types should be prepared for reliable results. Nevertheless, there was no report using such controls in the 

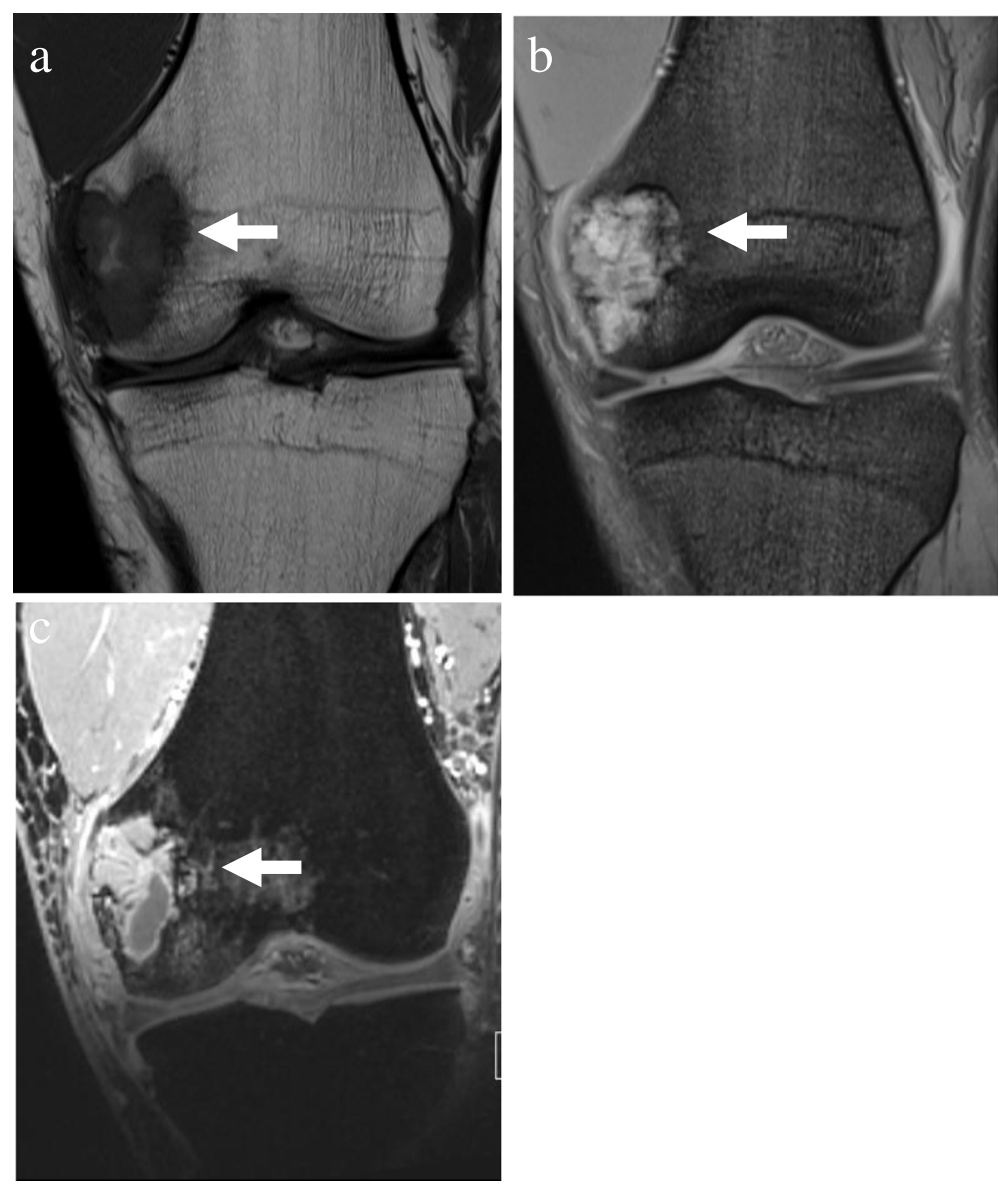

Fig. 3 Magnetic resonance imaging shows an ill-defined mass lesion in the left distal femur. Ill-defined mass lesion appears (a) hypointense on T1-weighted image and (b) hyperintense and isointense on T2-weighted image. c T1-weighted image with gadolinium shows primary enhancement at mass lesion excluding small non-enhancement area

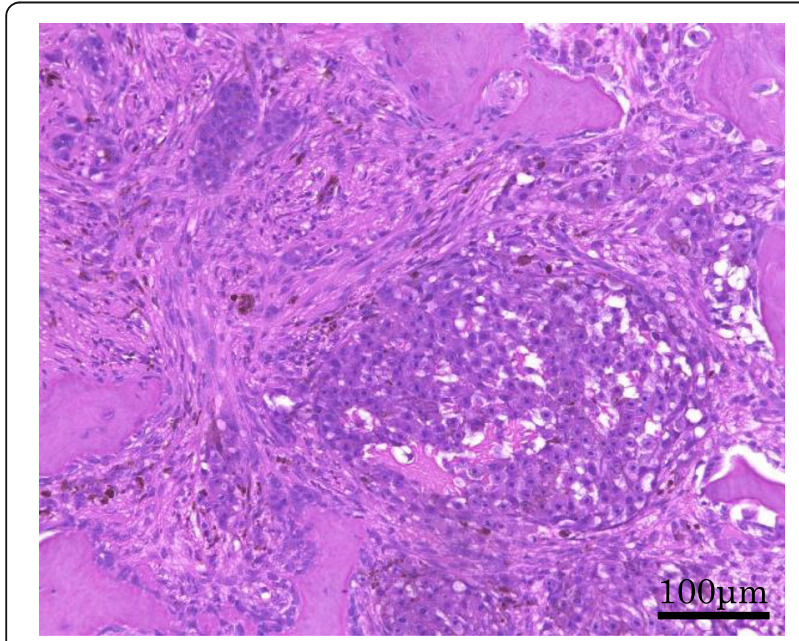

Fig. 4 Histological examination of the biopsy specimen reveals cell proliferation in oval or rounded cells. Images show hematoxylin and eosin staining. The tumors consist of fascicles and compact nests with frequent deposits of brown pigment. Magnification: $200 \times$ diagnosis of primary CCS of the bone. Therefore, it is better to perform direct sequencing to confidently diagnose the tumor as a primary CCS especially at very rare site such as bone.

Here, we have reported the first case of primary CCS of the bone diagnosed by detection of the fusion gene using RT-PCR and direct sequencing.

In this case, we confirmed there were no other primary tumors using MRI and whole-body CT scans. According to Gonzaga et al., [41] 13 of the 489 cases of CCS of soft tissue (3\%) had bone metastasis at diagnosis. These 13 cases were classified as American Joint Committee on Cancer (AJCC) stage IV and their probability of 5 -year survival was $15 \%$, and median overall survival was 8.9 months. Kawai et al. [2] showed that the cases which first metastasis site was bone were three out of the 52 cases of CCS $(5.8 \%)$ and the median time to metastasis was 13 months. Tumors $>5 \mathrm{~cm}$ had a 


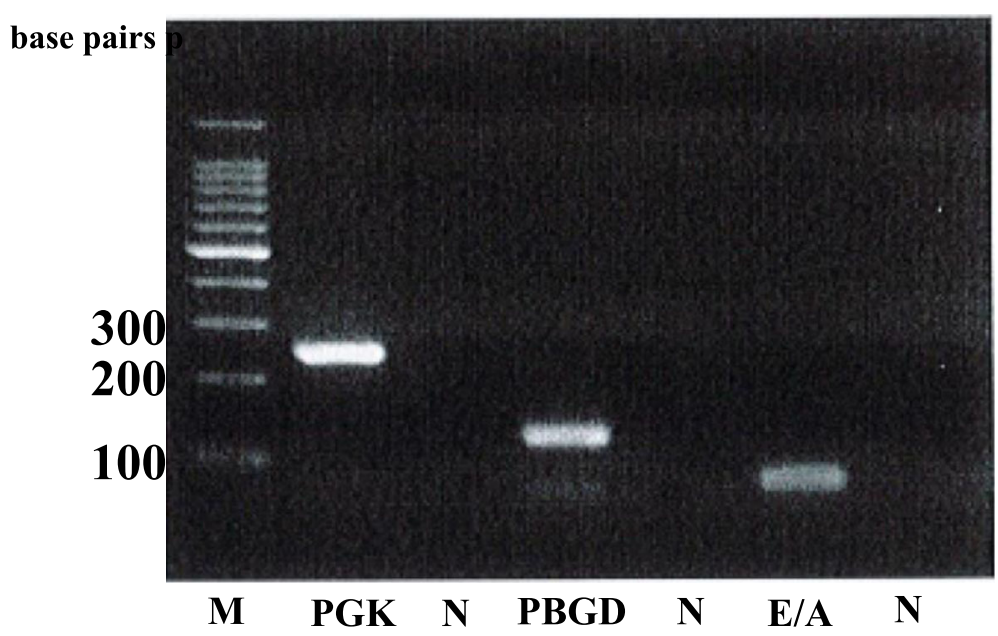

Fig. 5 Reverse transcription-polymerase chain reaction using EWSR1/ATF1 primer (81 base pairs). M: molecular size marker; N: negative control (distilled water); PGK: phosphoglycerate kinase, 247 base pairs; PBGD: porphobilinogen deaminase, 127 base pairs; E/A: EWSR1/ATF1 primer, 81 base pairs

significantly higher rate of metastases (79\%) than smaller tumors $(48 \%)$. Large CCS primary tumors consistently lead to metastases. Lucas et al. [42] reported that all 12 cases with tumors larger than $5 \mathrm{~cm}$ developed metastases. As metastases are usually derived from larger tumors (greater than $5 \mathrm{~cm}$ ) and bone metastases from CCS are rare, it is unlikely that a primary CCS would have been missed. Additionally, our patient had no local recurrence or metastasis for nine months after surgery. Together this allowed us to obtain a diagnosis of primary CCS of the bone.

In conclusion, to our best knowledge, this is the first case of primary CCS of the bone definitively diagnosed by detecting the fusion gene using RT-PCR and direct sequencing, and the first primary CCS of the bone arising in the femur. Because primary CCS of bone is exceedingly rare, it is important for definitive diagnosis to perform the most sensitive and accurate tests to confirm the presence of the characteristic fusion genes in order to obtain a definitive diagnosis.

\section{Abbreviations}

CCS: Clear cell sarcoma; CT: Computed tomography; FISH: Fluorescence in situ hybridization; MRI: Magnetic resonance imaging; PET: Positron emission tomography; RT-PCR: Reverse transcription polymerase chain reaction;

CDF: Continuous disease free; DOD: Died of disease; AWD: Alive with disease

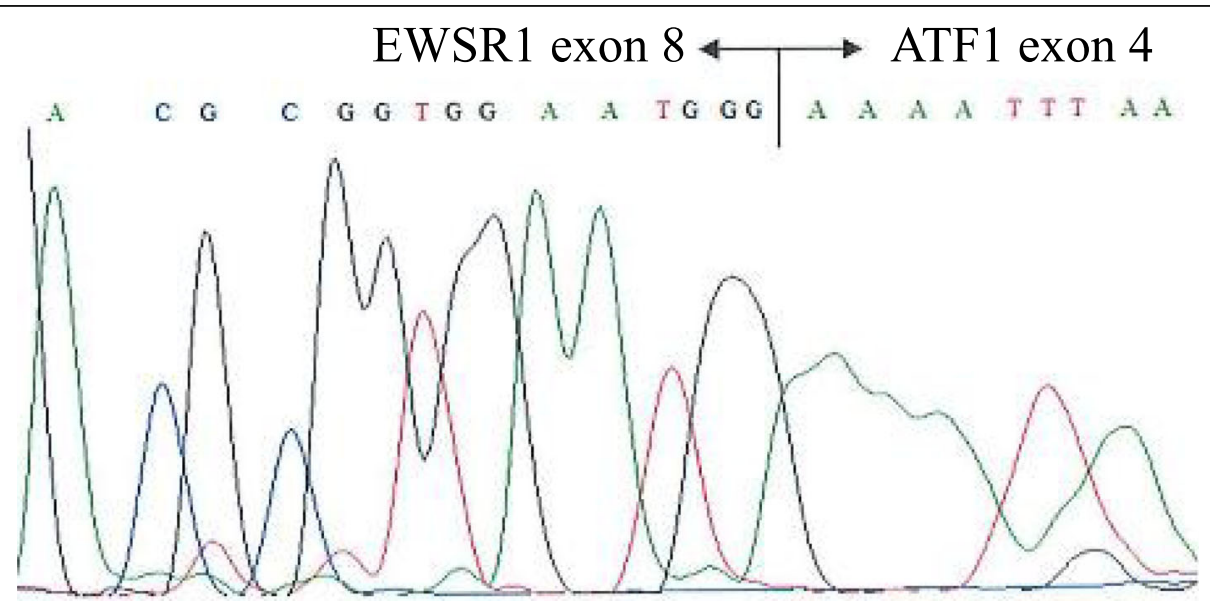

Fig. 6 Partial sequence of the RT-PCR products corresponding to the EWSR1/ATF1 fusion gene. RT-PCR, reverse transcription polymerase chain reaction 


\section{Acknowledgements}

We would like to thank Editage (www.editage.com) for English language editing by native English editors.

\section{Author' contributions}

The conception and design of the study: YK, KT and HT. Drafting the manuscript: YK and KT. Analysis and interpretation of data: YK, KT, MK, MH and TD. Critical revision of the manuscript for important intellectual content: $M H, T D$ and HT. Surgery performance: KT, MK, IT and II. All authors have read and approved the final version of the manuscript.

\section{Funding}

The authors received no financial support for the research, authorship, and/ or publication of this article.

\section{Availability of data and materials}

The datasets used and/or analyzed during the current study are available from the corresponding author on reasonable request.

\section{Ethics approval and consent to participate}

All procedures performed in this case report involving the patient were in accordance with the ethical standards of the local ethics committee.

\section{Consent for publication}

Written informed consent was obtained from the patient for publication of this case report and any accompanying images. A copy of the written consent is available for review by the Editor of this journal. The design of the work conforms to standards currently applied in the country of origin.

\section{Competing interests}

The authors declare that they have no competing interests.

\section{Author details}

'Department of Orthopaedic Surgery, Faculty of Medicine, Oita University, 1-1 Idaigaoka Hasama, 879-5593 Yufu City, Oita, Japan. ${ }^{2}$ Department of Pathology and Oncology, School of Medicine, University of Occupational and Environmental Health, 1-1 Iseigaoka, Yahatanishi-ku, 807-8555 Kitakyushu, Japan. ${ }^{3}$ Department of Diagnostic Pathology, Faculty of Medicine, Oita University, 1-1 Idaigaoka Hasama, 879-5593 Yufu City, Oita, Japan.

Received: 21 October 2020 Accepted: 11 January 2021

Published online: 21 January 2021

\section{References}

1. Enzinger FM. Clear-cell sarcoma of tendons and aponeuroses. An analysis of 21 cases. Cancer. 1965;18:1163-74.

2. Kawai A, Hosono A, Nakayama R, Matsumine A, Matsumoto S, Ueda T, et al. Clear cell sarcoma of tendons and aponeuroses: A study of 75 patients. Cancer. 2007;109:109-16.

3. Yokoyama R, Mukai K, Hirota T, Beppu Y, Fukuma H. Primary malignant melanoma (clear cell sarcoma) of bone: report of a case arising in the ulna. Cancer. 1996;77:2471-5.

4. Brekke MK, Northcote $K$, Temple WE. Clear cell sarcoma in the first metatarsal. An unusual case. J Am Podiatr Med Assoc. 1998;88:457-61.

5. Gelczer RK, Wenger DE, Wold LE. Primary clear cell sarcoma of bone: a unique site of origin. Skeletal Radiol. 1999;28:240-3.

6. Inaoka T, Takahashi K, Tandai S, Miyokawa N, Abe Y, Matsuno T, et al. Primary clear cell sarcoma (malignant melanoma) in the right radius. Skeletal Radiol. 2003;32:594-7.

7. Choi JH, Gu MJ, Kim MJ, Bae YK, Choi WH, Shin DS, et al. Primary clear cell sarcoma of bone. Skeletal Radiol. 2003;32:598-602.

8. Hersekli MA, Ozkoc G, Bircan S, Akpinar S, Ozalay M, Tuncer I, et al. Primary clear cell sarcoma of rib. Skeletal Radiol. 2005;34:167-70.

9. Kazakos CJ, Galanis VG, Giatromanolaki A, Verettas DA, Sivridis E. Clear cell sarcoma of the scapula. A case report and review of the literature. World $J$ Surg Oncol. 2006;4:48.

10. Rocco G, de Chiara AR, Fazioli F, Scognamiglio F, La Rocca A, Apice G, et al. Primary giant clear cell sarcoma (soft tissue malignant melanoma) of the sternum. Ann Thorac Surg. 2009;87:1927-8.

11. Zhang W, Shen Y, Wan R, Zhu Y. Primary clear cell sarcoma of the sacrum: a case report. Skeletal Radiol. 2010;40:633-9.
12. Liu X, Zhang H, Dong Y. Primary clear cell sarcoma of humerus: case report. World J Surg Oncol. 2011;9:163

13. Nakayama S, Yokote T, Iwaki K, Akioka T, Miyoshi T, Hirata Y, et al. A rare case of primary clear cell sarcoma of the pubic bone resembling small round cell tumor: an unusual morphological variant. BMC Cancer. 2012;12: 538.

14. Licata L, Fenga D, Speciale G, Rosa MA. Clear cell sarcoma of metatarsus . Folia Medica. 2014:56:271-4.

15. Xu Z, Suo H, Zhang Y, Feng W. Primary clear cell sarcoma of the calcaneus: Report of a rare case and review of the literature. Orthopade. 2019;48:232-8.

16. Yokoyama R. Primary clear cell sarcoma of bone. Skeletal Radiol. 2000;29: 302.

17. Panagopoulos I, Mertens F, Dêbiec-Rychter M, Isaksson M, Limon J, Kardas I, et al. Molecular genetic characterization of the EWS/ATF1 fusion gene in clear cell sarcoma of tendons and aponeuroses. Int J Cancer. 2002;99:560-7.

18. Coindre JM, Hostein I, Terrier P, Bouvier-Labit C, Collin F, Michels JJ, et al. Diagnosis of clear cell sarcoma by real-time reverse transcriptasepolymerase chain reaction analysis of paraffin embedded tissues: clinicopathologic and molecular analysis of 44 patients from the French sarcoma group. Cancer. 2006;107:1055-64.

19. Hisaoka M, Ishida T, Kuo TT, Matsuyama A, Imamura T, Nishida K, et al. Clear cell sarcoma of soft tissue: a clinicopathologic, immunohistochemical, and molecular analysis of 33 cases. Am J Surg Pathol. 2008;32:452-60.

20. Curry CV, Dishop MK, Hicks MJ, Naeem R, Reed JA, López-Terrada DH. Clear cell sarcoma of soft tissue: Diagnostic utility of fluorescence in situ hybridization and reverse transcriptase polymerase chain reaction. J Cutan Pathol. 2008:35:411-7.

21. Antonescu CR, Tschernyavsky SJ, Woodruff JM, Jungbluth AA, Brennan MF, Ladanyi M. Molecular diagnosis of clear cell sarcoma: detection of EWSATF1 and MITF-M transcripts and histopathological and ultrastructural analysis of 12 cases. J Mol Diagn. 2002;4:44-52.

22. Ferrari A, Casanova M, Bisogno G, Mattke A, Meazza C, Gandola L, et al. Clear cell sarcoma of tendons and aponeuroses in pediatric patients: a report from the Italian and German Soft Tissue Sarcoma Cooperative Group. Cancer. 2002:94:3269-76.

23. Nedoszytko B, Mrózek K, Roszkiewicz A, Kopacz A, Swierblewski M, Limon J. Clear cell sarcoma of tendons and aponeuroses with $\mathrm{t}(12 ; 22)$ (q13;q12) diagnosed initially as malignant melanoma. Cancer Genet Cytogenet. 1996; 91:37-9.

24. Pletneva MA, Andea A, Palanisamy N, Betz BL, Carskadon S, Wang M, et al. Clear cell melanoma: a cutaneous clear cell malignancy. Arch Pathol Lab Med. 2014;138:1328-36.

25. Ozuguz P, Kocak M, Atasoy P, Vargel I, Cavusoglu T. Clear cell sarcoma. Indian Dermatol Online J. 2014;5:488-90.

26. Davis IJ, Kim JJ, Ozsolak F, Widlund HR, Rozenblatt-Rosen O, Granter SR, et al. Oncogenic MITF dysregulation in clear cell sarcoma: defining the MiT family of human cancers. Cancer Cell. 2006;9:473-84.

27. Hocar O, Le Cesne A, Berissi S, Terrier P, Bonvalot S, Vanel D, et al. Clear cell sarcoma (malignant melanoma) of soft parts: a clinicopathologic study of 52 cases. Dermatol Res Pract. 2012:2012:984096.

28. Carlson JA, Ross JS, Slominski AJ. New techniques in dermatopathology that help to diagnose and prognosticate melanoma. Clin Dermatol. 2009;27:75102.

29. Thway K, Folpe AL. Update on selected advances in the immunohistochemical and molecular genetic analysis of soft tissue tumors. Virchows Arch. 2020;476:3-15.

30. Zucman J, Delattre O, Desmaze C, Epstein AL, Stenman G, Speleman F, et al. EWS and ATF-1 gene fusion induced by $\mathrm{t}(12 ; 22)$ translocation in malignant melanoma of soft parts. Nat Genet. 1993;4:341-5.

31. Antonescu CR, Nafa K, Segal NH, Dal Cin P, Ladanyi M. EWS-CREB1: a recurrent variant fusion in clear cell sarcoma - association with gastrointestinal location and absence of melanocytic differentiation. Clin Cancer Res. 2006;12:5356-62.

32. Fon GT, Wong WS, Gold RH, Kaiser LR. Skeletal metastasis of melanoma radiographic, scintigraphic, and clinical review. AJR Am J Roentgenol. 1981; 137:103-8.

33. Martí NB, Del pozo ES, Casals AA, Garrote JI, Masferrer NM. Falsepositive results obtained by following a commonly used reverse transcription-PCR protocol for detection of influenza A virus. J Clin Microbiol. 2006;44:3845. 
34. Kim HJ. Improved diagnosis of spring viremia of carp by nested reversetranscription PCR: development of a chimeric positive control for prevention of false-positive diagnosis. J Virol Methods. 2012;185:39-42.

35. Lin L, Carlqquist J, Sinclair W, Hall T, Lopansri BK, Bennett ST. Experience with false positive test results on the TaqPath real-time reverse transcription-PCR COVID-19 testing platform. Arch Pathol Lab Med. 2020 https://doi.org/10.5858/arpa.2020-0612-LE.

36. Kusk MS, Lausten-Thomsen U, Andersen MK, Olsen M, Hjalgrim H, Schmiegelow K. False positivity of ETV6/RUNX1 detected by FISH in healthy newborns and adults. Pediatr Blood Cancer. 2014;61:1704-6.

37. Alnahhas I, Rayi A, Thomas D, Ong S, Giglio P, Puduvalli V. False-positive 1p/ $19 q$ testing results in gliomas: clinical and research consequences. Am J Clin Oncol. 2020;43:802-5.

38. Ball MK, Kollmeyer TM, Praska CE, McKenna ML, Giannini C, Raghunathan A, et al. Frequency of false-positive FISH 1p/19q codeletion in adult diffuse astrocytic gliomas. Neurooncol Adv. 2020;2:vdaa109.

39. Patel RM, Downs-kelly E, Weiss SW, Folpe AL, Tubbs RR, Tuthill RJ, et al. Dual-color, break-apart fluorescence in situ hybridization for EWS gene rearrangement distinguishes clear cell sarcoma of soft tissue from malignant melanoma. Mod Pathol. 2005;18:1585-90.

40. Aslanzadeh J. Preventing PCR amplification carryover contamination in a clinical laboratory. Ann Clin Lab Sci. 2004;34:389-96.

41. Gonzaga MI, Grant L, Curtin C, Gootee J, Silberstein P, Voth E. The epidemiology and survivorship of clear cell sarcoma: a National Cancer Database (NCDB) review. J Cancer Res Clin Oncol. 2018;144:1711-6.

42. Lucas DR, Nascimento AG, Sim FH. Clear cell sarcoma of soft tissues. Mayo Clinic experience with 35 cases. Am J Surg Pathol. 1992;16:1197-204.

\section{Publisher's Note}

Springer Nature remains neutral with regard to jurisdictional claims in published maps and institutional affiliations.

Ready to submit your research? Choose BMC and benefit from:

- fast, convenient online submission

- thorough peer review by experienced researchers in your field

- rapid publication on acceptance

- support for research data, including large and complex data types

- gold Open Access which fosters wider collaboration and increased citations

- maximum visibility for your research: over $100 \mathrm{M}$ website views per year

At $\mathrm{BMC}$, research is always in progress.

Learn more biomedcentral.com/submissions 